\title{
Services Marketing and Poverty Reduction: A Case study on Dhaka City in Bangladesh
}

\author{
Mohammad Zahedul Alam ${ }^{1}$, and AHM Yeaseen Chowdhury ${ }^{2}$
}

\begin{abstract}
This research examines the interrelationships between services marketing and poverty alleviation in Dhaka City. Poverty alleviation is currently a major concern for many developing countries like Bangladesh. During the last one and half decades of socio-economic reforms in Dhaka city, rapid growth rate in the services sector has been recorded in terms of services activities, earnings, employment and contribution to GDP of the country. In some instance, economic growth alone cannot solve the poverty problem. As Dhaka city is rapidly becoming a major hub of all services sector, it is worthwhile to examine the effects of this industry on poverty alleviation through the enhancement of the nation's economy and the improved livelihoods of the people in the city areas. The growth of formal services is increasing day by day, but there is no scope for poor or illiterate people to participate in these sectors. Although, informal services sector has been increased, but the poor still remain poor for long time.
\end{abstract}

Key World---Services Marketing, Services Economy, Socioeconomic development, Poverty reduction, Dhaka City etc.

\section{INTRODUCTION}

$\mathrm{T}$ HE days of Adam Smith, David Ricardo and Karl Marx are gone when services were viewed as unproductive and the mention of trade in services was hardly found in economics literature. However, things have changed since then. Service sector is the largest sector of the world. 63.5 percent of total global wealth comes from services sector. United States is the largest producer of services sector with around 13.5 trillion USD. Services sector is the largest sector of 194 countries. 30 countries receive more than 80 percent of their GDP from services sector (Statistics Times, 2015). Now services play significant role to the Economy of the world. At present, the economy of Bangladesh depends on the growth of the services sector. Economic growth of Bangladesh is compiled of three main sectors. The major sectors in this issue are: a) Agriculture (18.64\%) b) Industry (28.61\%) c) Service (52.76\%) (BBS, 2011).

The role of services has expanded in about $80 \%$ of the Asia and Pacific region since 2000 and now generates at least half of GDP in nearly two-thirds of the region's reporting economies (Key indicators for the Asia and the pacific, 2015). Dhaka, the capital city of Bangladesh is the hub of all services sector of Bangladesh. So the economic structure of Dhaka city

\footnotetext{
${ }^{1}$ Associate Professor of Marketing, Bangladesh University of Professionals

${ }^{2}$ Associate Professor of Finance and Banking, Bangladesh University of Professionals
}

is dominated by the services sector. Most of the slum living people are directly or indirectly involved in formal or informal services sector since most of them are illiterate, unskilled and semi-skilled. Slum living people struggle to survive and adapt to the transition of the economy of Bangladesh. The growth and development of the services marketing in Dhaka city are remarkable in recent years. So, it is essential to examine the relationship between services marketing and poverty alleviation in Dhaka City. Importance of services sector in economy is growing rapidly such as Services account for more than 60 percent of GDP worldwide, almost all economies have a substantial service sector, most new employment is provided by services, strongest growth area for marketing.

\section{CONTRIBUTION OF AGRICULTURE, INDUSTRIES AND SERVICES SECTOR TO GDP IN BANGLADESH FROM LATE 1950 TO TILL NOW \\ TABLE NO. I}

SECTOR WISE GDP CHANGE IN PERCENTAGE

\begin{tabular}{|c|c|c|c|c|}
\hline \multirow{2}{*}{ Year } & \multicolumn{4}{|c|}{ Sector Wise GDP Change in percentage } \\
\cline { 2 - 5 } & Agriculture & Industry & Service & Total \\
\hline $1941-1950$ & 70 & 4 & 26 & 100 \\
\hline $1951-1960$ & 62 & 5 & 33 & 100 \\
\hline $1961-1970$ & 55 & 10 & 35 & 100 \\
\hline $1971-1980$ & 44 & 11 & 45 & 100 \\
\hline $1981-1990$ & 32 & 12 & 56 & 100 \\
\hline $1991-2000$ & 25 & 15 & 60 & 100 \\
\hline $2001-2011$ & 18 & 30 & 52 & 100 \\
\hline $2012-2016$ & 17.2 & 28.9 & 53.9 & 100 \\
\hline
\end{tabular}

[Source: www.worldbank.org \&

https://www.cia.gov/library/publications/the-worldfactbook/ Fields/2012.html]

The services sector growth rate during 1981-2000, service sector's contribution went higher than average. Now service sector has decreased to $53.9 \%$ of total GDP.

TABLE NO. II

COMPARISON OF SECTOR-WISE CONTRIBUTION TOWARDS GDP AMONG SELECTED COUNTRIES

\begin{tabular}{|l|l|c|c|c|}
\hline \multirow{2}{*}{$\begin{array}{c}\text { Country } \\
\text { Category }\end{array}$} & \multirow{2}{*}{$\begin{array}{c}\text { Country } \\
\text { Name }\end{array}$} & \multicolumn{3}{|c|}{ Sector wise contribution (2012 est) } \\
\cline { 3 - 5 } & & Agro & Manufacturing & Services \\
\hline Developed & USA & $1.1 \%$ & $19.2 \%$ & $79.7 \%$ \\
\hline Developing & Malaysia & $14.4 \%$ & $40.2 \%$ & $48.3 \%$ \\
\hline Wealth Rich & $\begin{array}{l}\text { South } \\
\text { Arabia }\end{array}$ & $1.9 \%$ & $64.8 \%$ & $33 . \%$ \\
\hline SAARC & India & $17.4 \%$ & $26.1 \%$ & $56.5 \%$ \\
\hline Custom & China & $10.1 \%$ & $45.3 \%$ & $44.6 \%$ \\
\hline
\end{tabular}

In developed country, maximum contribution of GDP comes from the service sectors. 


\section{RELEVANT LITERATURE REVIEW}

Very few articles have been found regarding the services marketing and poverty reduction in Bangladesh. Massimiliano Cali (2008) pointed that service sectors are a key part of the investment climate, and can have a much wider impact on overall business performance and the level of investment, and hence growth and productivity in the economy. The service sector represents $76 \%$ of the activity in the USA while in Europe figures indicate around $65 \%$. With regard to employment figures, it generates more than $80 \%$ of jobs in the U.S. and almost $70 \%$ in Europe (Sang M. Lee, 2006). Throughout the latter half of the twentieth century, the service sector has been both the largest and the fastest growing component of the U.S. economy. Fifty years ago, the service sector accounted for about sixty percent of U.S. output and employment. Today, the service sector's share of the U.S. economy has risen to roughly 80 percent (Douglas B. Cleveland, 1999).

The maturing of the manufacturing sector in many Asian countries, combined with the relative backwardness of its services sector, has made services sector development a top priority for developing Asia (Marcus Noland, 2012).

Poverty refers to various forms of economic, social and psychological deprivation among the people who lack adequate ownership, control over or access to resources for achieving a minimum level of living. It is a multidimensional problem involving income, consumption, nutrition, health, education, housing, crisis coping capacity, access to credit and other aspects of living (Poverty Monitoring Survey-2004). The World Bank (2000) World Development Report defines poverty as an unacceptable deprivation in human well-being that can comprise both physiological and social deprivation.

While global poverty fell during the 1990s, the numbers of urban poor people rose (Ravallion, Chen and Sangraula 2007). In many developing countries more than half of the urban population lives below the national poverty line (World Bank, 2003; UN Millennium Project, 2005). Recent economic crisis has made their situation worse (Jones and Corbridge 2010), causing many urban families to cut expenditure on food and children's education (Horn 2011). Many of the urban poor live in extremely poor conditions, in informal settlements with limited access to services (Baker 2008). Both government-run services and non-governmental organizations tend to neglect the urban poor. Poverty reduction strategies and national education plans rarely mention slums or urban poverty. Particularly in the least developed countries, the focus is still largely on rural poverty (Mitlin 2004; UNESCO-IIEP 2009), and few international agencies make specific provision for children in urban areas (Bartlett 2009).

Today, service industries are the sources of economic leadership. During the past 30 years, more than 44 million new jobs have been created in the services sector to absorb the influx of women into the workforce and to provide an alternative to the lack of job opportunities in manufacturing (US Govt, 1999). Above and beyond, the major employment opportunities in developed and developing countries are also largely contributed by services sector (Breen \& Crawford, 2004). According to Haveman and Schwabish (2000), economic growth and poverty rates showed a negative relationship until 1970s. However, starting from the late 1970s, this relationship between economic growth and the poverty rates became statistically unclear.

Chen and Wang (2001) used household survey data for 1990 to 1999 to empirically show that the poor have gained far less from economic growth than the rich, and that only 20 per cent of the richest had income growth equivalent to, or greater than, GDP growth. As a result, rising income inequality disconnects poverty alleviation from economic growth.

In general, slums are the products of failed policies, bad governance, corruption, inappropriate regulation; dysfunctional land markets, unresponsive financial systems and a fundamental lack of political will (Shirin, 2012). Although the paper examines these phenomena in the specific case of the Dhaka City, the analysis has much wider application, both for economic policy and for theories of growth and structural change.

\section{THE PURPOSES OF THIS STUDY ARE:}

- To analyze the service sectors and present scenario of services marketing in Bangladesh.

- To analyze the role of services marketing in poverty reduction of Dhaka city in Bangladesh.

- To offer some suggestions and recommendations for the development of services marketing thought in Bangladesh.

\section{Research Questions:}

1. Does services marketing play significant role in poverty reduction in Dhaka City?

2. How does the sectoral pattern of growth affect its poverty impact?

3. Does the services sector act as new engine for economic growth of Bangladesh?

4. What policies may facilitate the poor's participation in growth?

\section{Methodology}

The study is both descriptive and exploratory in nature. For the purpose of the study, data have been collected from both the secondary and primary sources. For collecting the primary data, a structured questionnaire has been designed to collect the information from the respondents. Both open ended and multiple-choice questions have been used in questionnaire. Primary data have been collected through personal interview, focus groups and depth interview with the slum living people in Dhaka City. Dhaka City is chosen as the case study, because Dhaka city faces the challenges of urban poverty and it is the hub of all services sector in Bangladesh. For the purpose of the study, 200 slum living people have been interviewed in different slum areas of Dhaka City. Simple random sampling techniques have been used to select the sample size. For analyzing the collected data, SPSS software has been used to find out the findings of the study.

\section{V.AN OVERVIEW OF THE SLUM AND POVERTY SCENARIO IN DHAKA CITY:}

Poverty and Slums in Dhaka City

Bangladesh has been known as one of the world's poorest countries of the world. 


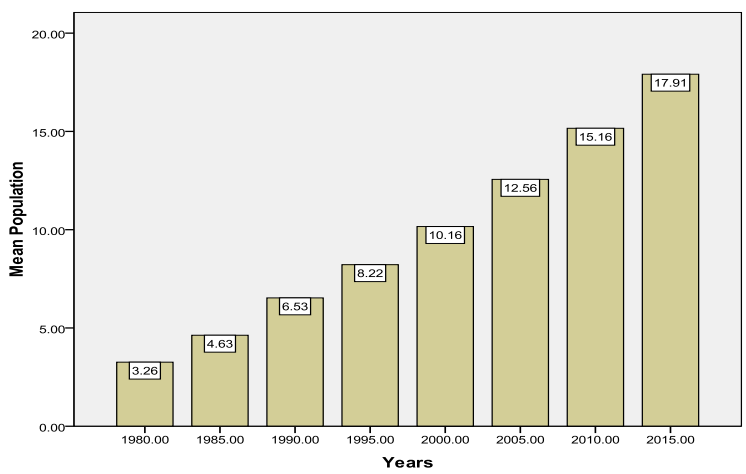

Fig 1 Population Explosion of Dhaka Megacity (In millions) Sources: World Urbanization Prospects, The 2003 revision, UN

Due to this high growth rate, Dhaka's share of the country's total population has been steadily growing, currently at over $10 \%$. By 2015 , almost $13 \%$ of Bangladesh's total population, a staggering 22 million people, will call Dhaka their home. (Cities in Globalization world, UN, 2015)

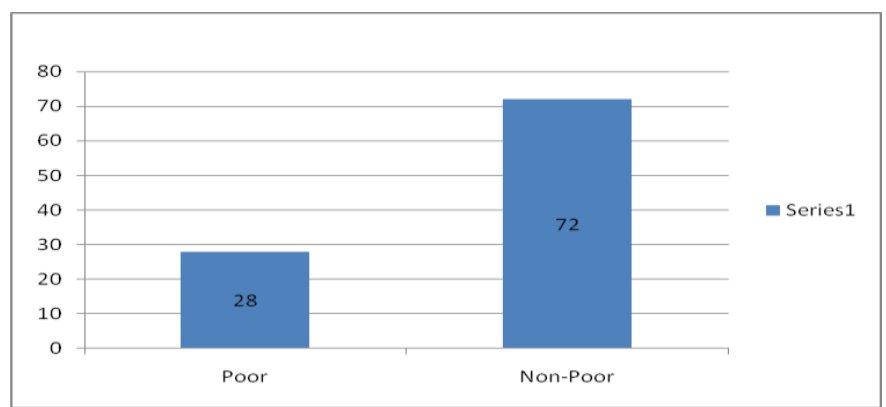

Fig 2 Poor and Non-Poor Proportion of Dhaka City Sources: Sustainable development networking website.

TABLE NO. III

BANGLADESH POVERTY CONDITION

\begin{tabular}{|l|l|}
\hline Poverty Indicators of Bangladesh & Poverty line \\
\hline Number of rural poor (million) & 101.0 \\
\hline Poor as \% of total rural population & 53.0 \\
\hline Population living below US \$ 1 a day (\%) & 36.0 \\
\hline Population living below US\$2 a day (\%) & 82.8 \\
\hline $\begin{array}{l}\text { Population living below the national poverty } \\
\text { line (\%) }\end{array}$ & 49.8 \\
\hline Poverty gap ratio at US \$ 1 a day (\%) & 8.0 \\
\hline $\begin{array}{l}\text { Share of poorest 20\% in national income or } \\
\text { consumption (\%) }\end{array}$ & 9.0 \\
\hline
\end{tabular}

Sources: UNDP, 2007

TABLE No. IV

POVERTY LINE IN BANGLADESH

\begin{tabular}{|c|c|c|c|}
\hline $\mathbf{1 9 9 5}$ & $\mathbf{2 0 0 4}$ & $\mathbf{2 0 0 8}$ & $\mathbf{2 0 1 0}$ \\
\hline 35.6 & 45 & 36.3 & 31.50 \\
\hline
\end{tabular}

Sources: World Bank, 2010

Bangladesh has experienced one of the most rapid urban growth rates in recent times. The urbanization of the country is characterized by an overwhelming concentration of population in metropolitan areas, especially in Dhaka. As one walks through Dhaka, the pervasive poverty is evident, as is the inequality between rich and poor. As Dhaka is well linked to the entire country by land, water and air, and can be reached within a day from any part of the country, there are opportunities for migrants to arrive in the city using transport within their reach. The majority of urban poor migrate to Dhaka City from a few districts like Faridpur, Barisal and Comilla. The rural poor migrate to Dhaka City due to some push and pull factors. The factors include over-population, floods and natural disasters, river erosion, growing landlessness and exploitation by the rural elites and moneylenders. Along with push factors the pull factors also contribute to the increasing rural-urban migration in Bangladesh. These pull factors are mainly employment opportunities in the informal sectors of the economy, better opportunities in the city and relative freedom for female workers. The slum population in Dhaka city faces extreme poverty due to its low level of earnings and the majority is living below the poverty line in terms of both calorie intake and cost of basic needs. Slum dwellers in the city are disadvantaged in terms of their access to urban services like safe water, electricity, gas supply, toilet facilities and garbage disposal. The quality of these services has been found to be poor and the supply remains highly irregular and inadequate.

The poverty of slum population is an extension of rural poverty of Bangladesh which is dominated by the rural rich and which plays a strong role in maintaining and legitimizing poverty. Poverty is caused by the stagnation of productive forces and production overtime and government policies and development measures which help the rural rich to get richer and increase inequality.

\section{FINDINGS AND ANALYSIS}

Among the Asian countries, comparatively, most of the economy depends on services sector. Initially, Bangladesh economy depended on agricultural sectors, right now Bangladesh economy is shifting towards the services sector. Informed opinion about the prospects for the Bangladesh economy has changed enormously during the last decade. This is partly because of the country's huge advances in Information Technology (IT); but it is also due to new thinking with respect to the theory of economic development.

TABLE NO. $\mathrm{V}$

OPINIONS OF THE SLUM LIVING PEOPLE REGARDING THE SERVICES MARKETING IN DHAKA CITY

\begin{tabular}{|l|l|l|}
\hline \multicolumn{1}{|c|}{$\begin{array}{l}\text { Statement regarding the services sector in Dhaka } \\
\text { City }\end{array}$} & Yes & No \\
\hline Skills & 54 & 146 \\
\hline Service sector is making you self-employed & 166 & 34 \\
\hline $\begin{array}{l}\text { Do you think your income has lessened social } \\
\text { conflict? }\end{array}$ & 165 & 35 \\
\hline $\begin{array}{l}\text { The standard of living is increasing by working in } \\
\text { service sectors within recent years? }\end{array}$ & 142 & 58 \\
\hline self-esteem & 164 & 36 \\
\hline $\begin{array}{l}\text { Do you feel service job has increased your life } \\
\text { standard }\end{array}$ & 160 & 40 \\
\hline $\begin{array}{l}\text { Poverty reduction is due to growth and development } \\
\text { of services sector. }\end{array}$ & 96 & 104 \\
\hline $\begin{array}{l}\text { Resources have been increased due to the growth and } \\
\text { development of the services sector. }\end{array}$ & 51 & 149 \\
\hline Sanitation has been improved & 104 & 96 \\
\hline Is there any school in your area at present & 177 & 23 \\
\hline Are your children going to school & 187 & 13 \\
\hline Your children get proper education from school & 160 & 40 \\
\hline $\begin{array}{l}\text { Do you face any problem in working this service } \\
\text { sector? }\end{array}$ & 70 & 130 \\
\hline Sources: Field survey, 2016 & & \\
\hline
\end{tabular}

Sources: Field survey, 2016 
From the above table, it has been observed that services sector play significant role on social and economic development of slum living people in Dhaka City. Most of the respondents opined that services sector people play contributes to improve the socio-economic condition of slum living people in Dhaka city.

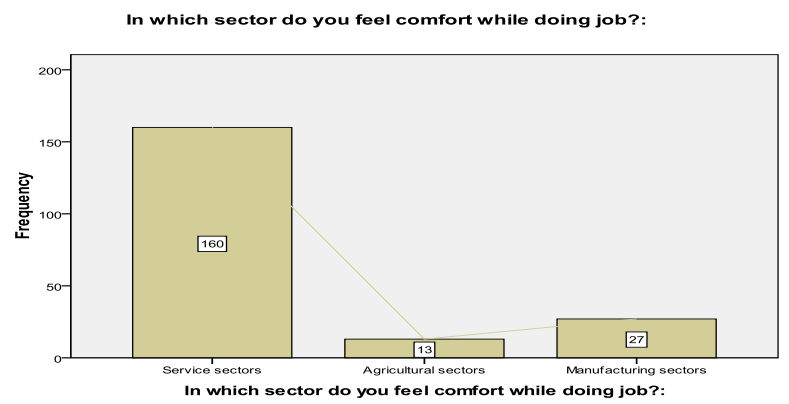

Fig. 3 Sector people feel comfort while doing job

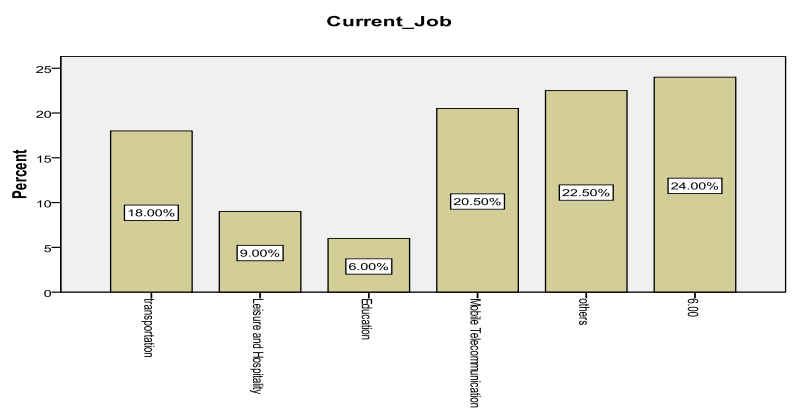

Fig. 4 Current Jobs in which Slum living engage

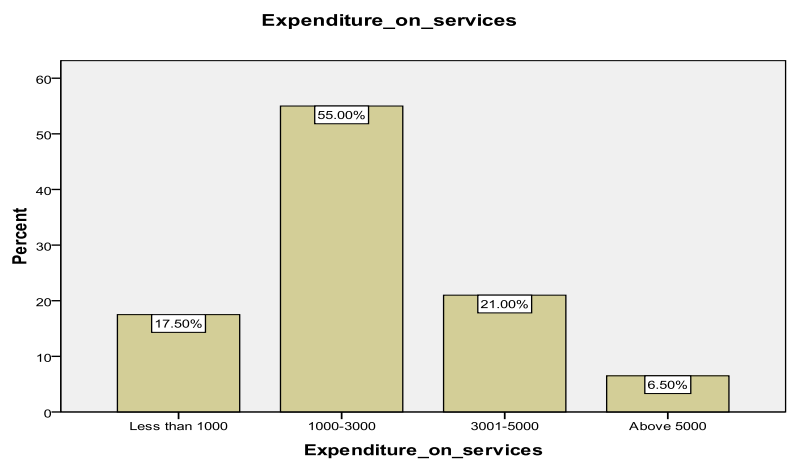

Fig. 5Expenditure on services

\section{RECOMMENDATIONS}

Services firm should employ the labor from the slum living qualified people in Dhaka City. Slum living people should be employed in formal services sector as quota basis. Services sector should take local services from the slum living people in Dhaka City. There is change to do ethical misconduct in services sector due to nature of services marketing. So, ethical issues should be monitored properly by the government of Bangladesh.

The people who are directly or indirectly involved in informal services activities should be recognized socially or officially. Upper class people should take services from the bottom of the pyramid in the society. Services sector should be more labor intensive rather than technology intensive to provide the services. Services sector should recruit unskilled manpower from the people who live under the poverty level in Dhaka City. Proper marketing programs should be developed targeting to the poor people so that they can get the proper information regarding the services. Services marketing campaign should use the poverty as the basis for market segmentation. Mega city should not be the hub of all services sector in Bangladesh. It should be spread across the country to provide the services to the poor people to alleviate the poverty. Some informal services are not recognized socially, people view it negatively. So, general people should view the services marketing like other productive sectors available across the country.

\section{CONCLUSION}

Services marketing is becoming a recognized and accepted subset of the marketing discipline. Given the growth of the services sector in economies throughout the world, and the almost universal belief by scholars working in this area that services marketing is in certain key respects different from goods marketing, the rapid growth of service marketing literature in recent years is not surprising. An acceleration of academic interest and research activity in services marketing in the years immediately ahead is to be expected and is necessary because far more questions than answers exist at this time. From the study, it has been observed that services marketing play significant role in poverty reduction in Dhaka city of Bangladesh. Services marketing have an impact on social and economic impact on slum living people in Dhaka city. Implied by the set of research implications reviewed above is the need for researchers to broadly about researchable issues and to be willing to work in areas not normally classified as marketing. A need exists for services marketing research to enter a new phase of empirical work that integrates various disciplines and various service industries.

\section{REFERENCES}

[1] Alamgir et al (2009). Assessing the livelihood of slum dwellers in Dhaka city. J. Bangladesh Agri. Univ., 7(2): 373-380.

[2] Bateson, John E.G. (1977), "Do We Need Services Marketing?" in Marketing Consumer Services: New Insights, Marketing Science Institute, Report\# 77-115

[3] Booms, Bernard H. and Mary J. Bitner (1981), "Marketing Strategies and Organization Structures for Services Firms," in Marketing of Services, Chicago: American marketing, pp. 47-51.

[4] Gronroos, Christian (1977), "The service Marketing Confusion and a Service Oriented Approach to Market Planning," European Journal of Marketing, 12 (no, 8), 588-601. https://doi.org/10.1108/EUM0000000004985

[5] Ger Guliz (1992) the positive and negative effects of marketing on socio-economic development: the Turkish case, Journal of consumer policy, Netherland, Volume: 15, pp: 229-254.

[6] Joshi, S., (2004) 'Tertiary Sector-Driven Growth in India- I mpact on Employment and Poverty', Economic and Political Weekly, Special Article, September 11, 2004.

[7] Islam Mohammad Shahidul (2012), "The Comparative Growth of Service Sectors in Bangladesh", Research Journal of Finance and Accounting, Vol no. 3 (5); pp: 178-182.

[8] Shirin S. Feminist Movement and Women Empowerment: Bangladesh Perspective. The Journal of Social Development 2012; 24 (1): 183-312.

[9] Douglas B. Cleveland (1999), The Role of Services in the Modern U.S. Economy Office of Service Industries. Read more: 
[10] Ravallion, M., S. Chen and P. Sangraula (2007). New Evidence on the Urbanization of Global Poverty. Population and Development Review, 33, 4, 667-701.

https://doi.org/10.1111/j.1728-4457.2007.00193.x

[11] Gronroos, Christian (1977), "The service Marketing Confusion and a Service Oriented Approach to Market Planning," European Journal of Marketing, 12 (no, 8), 588-601. https://doi.org/10.1108/EUM0000000004985

[12] World Bank (2000), World Bank Development Report, New York and Washington: Oxford University Press.

[13] Baker, J. L. (2008). Urban poverty: a global view. Urban Papers 5, Washington, D.C.: World Bank.

[14] Marcus Noland, Donghyun Park, and Gemma B. Estrada (2012), The Asian Development Bank, "Developing the Services Sector as Engine of Growth for Asia: An Overview",

Author: Mr. Md. Zahedul Alam was born in 1980 in Bangladesh. At present, he is an Associate Professor of Marketing, under the Faculty of Business Studies (FBS), Bangladesh University of Professionals (BUP); a well recognized Public University in Bangladesh run by the Armed forces. He received his BBA and MBA degree (major in Marketing) from University of Dhaka and received his M Phil degree from the University of Rajshahi. How he is pursuing $\mathrm{PhD}$ at Bangladesh University of Professionals (BUP). $\mathrm{He}$ attended in many national and international seminars. 